\title{
Analisis Kemampuan Pemahaman Konsep Matematis Ditinjau Dari Minat Belajar Siswa Pada Materi Himpunan Kelas VII SMP Negeri 8 Singkawang.
}

\author{
Dwi Pranajaya $^{1}$, Nurhayati ${ }^{2}$, Nindy Citroresmi Prihatingtyas ${ }^{3}$ \\ Program Studi Pendidikan Matematika, STKIP Singkawang, Singkawang, Indonesia \\ Dwipranajaya98@gmail.com ${ }^{1}$, nurhayati@stkipsingkawang.ac.id.', nindy.citroresmi@gmail.com³
}

\author{
Keywords : \\ kemampuan pemahaman \\ konsep, minat belajar.
}

\begin{abstract}
Permasalahan konsep yang kian mempersulit peserta didik untuk belajar matematika. Penelitian ini bertujuan untuk menganalisis pemahaman konsep matematis siswa dalam materi himpunan pada kelas VII SMPN 8 Singkawang. jenis penelitian yang digunakan adalah penelitian deskriptif berasal dari istilah bahasa inggris to describe yang berarti memaparkan atau menggambarkan sesuatu hal, misalnya keadaan, kondisi, atau hal lain-lain dengan demikian yang dimaksud dengan penelitian deskriptif yang hasilnya dipaparkan dalam bentuk penelitian, dengan pendekatan kualitatif. Instrumen penelitian yang digunakan pada penelitian ini adalah berkaitan dengan teknik pengumpulan data yang digunakan, maka alat pengumpulan data yang akan digunakan dalam penelitian ini adalah tes tertulis. Pengumpulan data melalui teknik tes dilakukan dengan memberikan instrumen tes yang terdiri dari seperangkat pertanyaan atau soal berupa soal tes kemampuan pemahaman konsep matematis siswa dan angket minat belajar untuk memperoleh keinginan siswa untuk belajar matematika. Penelitian ini menggunakan penelitian deskriptif, sehingga analisis data pengamatan penelitian ini juga diolah dengan analisis deskriptif untuk menggambarkan serta mendeskripsian keadaan pemahaman konsep matematis siswa dalam materi himpunan. Hasil penelitian Kemampuan pemahaman konsep matematis siswa dari 30 siswa dan hasil yang dilakukan peneliti di SMPN 8 Singkawang dengan kemampuan pemahaman konsep masuk dalam kategori tinggi dan minat belajar siswa masuk dalam kategori sedang. Faktor-faktor yang mempengaruhi pemahaman konsep dan minat belajar siswa dari materi himpunan yaitu : Faktor internal (dalam diri siswa) dan Faktor eksternal (lingkungan dan sekitar)
\end{abstract}

\section{PENDAHULUAN}

Tujuan Matematika adalah ilmu universal yang menjadi dasar perkembangan teknologi modern, mempunyai peran yang sangat penting dalam berbagai disiplin ilmu dalam meningkatkan kemajuan daya pikir manusia. Tidak dapat dipungkiri bahwa pesatnya perkembangan di semua bidang serta disiplin ilmu terutama bidang teknologi informasi dan komunikasi sekarang ini sangat didasari oleh perkembangan matematika Untuk lebih dapat mengusai dan menciptakan teknologi dimasa yang akan datang,berdasarkan pada Peraturan Menteri Pendidikan dan Kebudayaan Republik Indonesia Nomor 24 Tahun 2016 Tentang Kompetensi Inti dan Kompetensi Dasar Pelajaran Pada Kurikulum 2013 Pada Pendidikan sekolah SD, SMP, SMA dan SMK. 
Journal of Educational Review and Research

Vol. 3 No. 2, December 2020: 86 - 98

e-ISSN: 2597-9760, p-ISSN: 2597-9752

Pemahaman konsep merupakan dasar dan tahapan penting dalam rangkaian pembelajaran matematika sebagaimana yang diungkapkan oleh National Council of Teachers of Mathematics (2000:20), pemahaman konsep adalah suatu komponen penting dari kecakapan atau kemahiran matematika, pemahaman konsep termasuk learning princip pembelajaran yang dikemukakan oleh NCTM. Dalam learning principle siswa harus belajar matematika dengan aktif membangun pengetahuan baru dari pengalaman dan pengetahuan sebelumnya.Pemahaman konsep memungkinkan siswa untuk menggunakan pengetahuan mereka dengan fleksibel dan memecahkan permasalahan-permasalahan baru. Selain tercantum dalam learning principle, pemahaman konsep juga tercantum dalam tujuan pembelajaran matematika. Sebagaimana yang dinyatakan oleh Depdiknas(2013) yaitu sebagai berikut :(Pemahaman konsep matematika, menjelaskan konsep atau secara luwes, akurat, efisien dan tepat dalam pemecahan masalah, Menggunakan penalaran pada pola dan sifat, melakukan manipulasi matematika dalam membuat generalisasi, menyusun bukti atau menjelaskan gagasan dan peryatan matematika, Memecahkan masalah, Mengomunikasikan gagasan dengan simbol, tabel, diagram, atau media lain untuk memperjelas keadaan atau masalah, Memiliki sikap menghargai kegunaan matematika dalam kehidupan, sikap rasa ingin tau, perhatian, dan minat dalam mempelajari matematika, serta sikap ulet dan percaya diri dalam pemecahan masalah, dengan demikian pemahaman konsep merupakan kemampuan yang sangat penting dalam pembelajaran matematika).

Siswa harus memahami konsep terlebih dahulu dalam pembelajaran matematika menurut Syarifah (2014:6) konsep merupakan dasar bagi proses berpikir tingkat tinggi. Siswa yang memahami konsep dengan baik akan lebih dapat menggeneralisasikan dan mentransfer pengetahuan dari pada siswa yang hanya menghafal. Siswa dapat menyelesaikan soal-soal dan mampu mengaplikasikan pembelajaran ke dalam dunia nyata. Siswa yang tidak paham konsep akan kesulitan dalam mengerjakan soal jika berbeda dari contoh soal jenis apa pun siswa akan mampu mengerjakannya. Sehingga pemahaman konsep ini merupakan kemampuan yang mutlak harus dimiliki siswa. Selain itu, dengan berbekal kemampuan yang mutlak harus dimiliki siswa. Selain itu, dengan berbekal kemampuan dasar pemahaman konsep yang baik, maka siswa dapat mencapai kemampuan dasar yang lain seperti, penalaran, komunikasi, koneksi dan pemecahan masalah jadi dengan berbekal pemahaman konsep yang baik, maka penugasan siswa dalam matematika dapat tercapai dengan baik. Permasalahan konsep yang kian mempersulit peserta didik untuk belajar matematika kelas VII SMPN 8 Singkawang sebagian besar siswa kurang aktif di kelas yang ditunjukkan oleh beberapa hal yaitu: siswa kurang aktif bertanya kepada guru, kurang berinteraksi dengan siswa lain, siswa sulit mengajukan pendapat, serta kurangnya minat dan perhatian siswa terhadap kegiatan pembelajaran.

Pengertian Minat Belajar merupakan suatu keadaan di mana seseorang mempunyai perhatian terhadap sesuatu dan disertai keiinginan untuk mengetahui dan mempelajari maupun membuktikannya lebih lanjut. Minat timbul karena adanya perhatian yang mendalam terhadap suatu obyek, di mana perhatian tersebut menimbulkan keinginan untuk mengetahui, mempelajari, serta membuktikan lebih lanjut. Hal itu menunjukkan, bahwa dalam minat, di samping perhatian juga terkandung suatu usaha untuk mendapatkan sesuatu dari obyek minat tersebut. Minat belajar bertumpu pada prinsip bahwa individu yang belajar hanya akan sampai kepada perolehan hasil belajar, mulai keterampilan, pengembangan penalaran, pembentukan sikap sampai kepada penemuan diri sendiri, apabila ia mengalami sendiri dalam proses perolehan hasil belajar tersebut (Umar Tirtahardjo dan La Sulo, 2005). Belajar mandiri bukanlah belajar individual, akan tetapi belajar yang menuntut kemandirian seorang siswa untuk belajar. Menurut Martinis Yamin (2008) minat belajar adalah kemauan dalam belajar dan mendapat informasi dan pengetahuan yang tidak dikendalikan orang lain.

Minat belajar bertumpu pada prinsip bahwa individu yang belajar hanya akan sampai kepada perolehan hasil belajar, mulai keterampilan, pengembangan penalaran, pembentukan sikap sampai kepada penemuan diri sendiri, apabila ia mengalami sendiri dalam proses perolehan hasil belajar tersebut (Umar Tirtahardjo dan La Sulo, 2005). Menurut (Fahinu, 2013) menyatakan bahwa seseorang yang mempunyai minat belajar memiliki kemampuan untuk mengatur motivasi dirinya, tidak saja motivator eksternal tetapi juga motivator internal serta mampu menekuni tugas jangka panjang sampai tugas itu diselesaikan. (Fahmy,2018). Tidak adanya kemandirian pada siswa akan menghasilkan berbagai macam problem perilaku, misalnya pemalu, tidak punya motivasi sekolah, dan kebiasaan belajar yang buruk. akan berpengaruh kepada hasil belajarnya (Agung wirayat ,2015).yang memiliki minat belajar tinggi 
Journal of Educational Review and Research

Vol. 3 No. 2, December 2020: 86 - 98

e-ISSN: 2597-9760, p-ISSN: 2597-9752

cenderung belajar lebih baik, mampu memantau, mengevaluasi, dan mengatur belajarnya secara efektif, menghemat waktu dalam menyelesaikan tugasnya, mengatur belajar dan waktu secara efisien, dan bisa mencapai prestasi yang diingikan.

Salah satu faktor yang mempengaruhi prestasi belajar siswa adalah minat belajar. Minat belajar yang tinggi akan mendukung berlangsungnya proses belajar mengajar matematika. Minat besar pengaruhnya terhadap pelajaran, karena bila bahan pelajaran yang dipelajari tidak sesuai dengan minat siswa, siswa tidak akan belajar dengan sebaik-baiknya, karena tidak ada daya tarik baginya. Ia segan-segan untuk belajar, ia tidak memperoleh kepuasan dari pelajaran itu. Bahan pelajaran yang menarik minat siswa, lebih mudah dipelajari dan disimpan, karena minat menambah kegiatan(Slamet, 2003: 57). Sejalan dengan itu (Ahmadi,1990: 79) mengemukakan bahwa tidak adanya minat siswa terhadap suatu pelajaran akan timbul kesulitanbelajar, karena itu pelajaran pun tidak pernah terjadi proses dalam otak. Sehingga tujuan belajar tidak dapat terlaksana. Selanjutnya Usman (1993: 12) mengemukakan bahwa anak yang tergolong ke dalam berprestasi kurang ialah anak yang memiliki taraf intelegensi yang tergolong tinggi. Akan tetapi prestasi belajar yang dicapai termasuk rendah (di bawah rata-rata). Secara potensial anak yang bertaraf intelegensi tinggi memiliki kemungkinan yangbelajar cukup besar untuk memperoleh prestasi belajar yang tinggi.

Gejala berprestasi kurang ini sesungguhnya dirasakan sebagai salah satu masalah dalam belajar karena secara potensial mereka memiliki kemungkinan untuk memperoleh prestasi belajar yang lebih tinggi. Timbulnya gejala ini berkaitan dengan motivasi, minat, sikap dan kebiasaan belajar, ciri-ciri kepribadian tertentu dan pola-pola pendidikan yang diterima dari orang tuanya, serta suasana rumah tangga pada umumnya. Anak-anak dari golongan ini memerlukan perhatian yang sebaik-baiknya dari para guru, terutama dari para petugas bimbingan di sekolah. Anak yang mencapai suatu prestasi, sebenarnya merupakan hasil kecerdasan dan minat (Lisnawaty, 1993: 58). Jadi seorang siswa tidak mungkin sukses dalam segala aktivitas tanpa adanya minat. Minat dapat timbul pada seseorang jika menarik perhatian terhadap suatu obyek. Perhatian ini akan terjadi dengan sendirinya atau mungkin timbul karena ada pengaruh dari luar. Minat berpengaruh terhadap prestasi belajar siswa karena bila bahan pelajaran yang dipelajari tidak sesuai dengan minat siswa, maka siswa tidak akan belajar dengan baik. Sebaliknya siswa yang memiliki minat terhadap sesuatu pelajaran atau ilmu pengetahuan akan senang belajarsehingga dapat berhasil dalam pelajaran itu.

Himpunan merupakan kumpulan benda-benda atau objek-objek yang didefinisikan dengan jelas. Pada penelitian ini menggunakan materi himpnan untuk menganalisis kemampuan pemahaman konsep matematis siswa.

Berdasarkan permasalahan yang telah dipaparkan secara umum diatas maka peneliti tertarik melakukan penelitian dengan judul" Analisis kemampuan pemahaman konsep matematis ditinjau dari minat belajar siswa pada materi himpunan kelas VII SMPN 8 Singkawang".

\section{METODE}

Jenis penelitian ini adalah penelitian dengan pendekatan kualitatif. Pendekatan kualitatif adalah suatu pendekatan penelitian yang mengungkap situasi sosial tertentu dengan mendeskripsikan kenyataan secara benar, dibentuk oleh kata-kata berdasarkan teknik pengumpulan data dan relevan yang diperoleh dari situasi yang alamiah (Satori dan Komariah , 2015:25). Adapun jenis penelitian yang digunakan adalah penelitian deskriptif berasal dari istilah bahasa inggris to describe yang berarti memaparkan atau menggambarkan sesuatu hal, misalnya keadaan, kondisi, atau hal lain-lain dengan demikian yang dimaksud dengan penelitian deskriptif yang hasilnya dipaparkan dalam bentuk penelitian (Arikunto,2015:3).

Tempat dan waktu Penelitian ini dilakukan pada peneliti lakukan di SMP Negeri 8 Singkawang, beralamat di Jl. Planet No. 1A, kecamatan Singkawang Utara, Kelurahan Sungai Bulan, Provinsi Kalimantan Barat. Waktu Penelitian Penelitian ini dilakukan pada tahun ajaran 2019 semester ganjil. 
Journal of Educational Review and Research

Vol. 3 No. 2, December 2020: 86 - 98

e-ISSN: 2597-9760, p-ISSN: 2597-9752

Subjek dan Objek Penelitian Subjek Penelitian Menurut Arikunto (2015:188) subjek subjek penelitian adalah subjek yang dituju untuk diteliti oleh peneliti diantaranya adalah siswa kelas VII A di SMPN 8 Singkawang, untuk mengetahui kemampuan pemahaman konsep matematis siswa yang berjumlah 30 orang .

Tabel 1 Kriteria Kemampuan Pemahaman Konsep Matematis Siswa

\begin{tabular}{cc}
\hline Rentang Skor & Kriteria \\
\hline $3,0<\mathrm{N} \leq 4$ & Sangat tinggi \\
$2,6<\mathrm{N} \leq 3$ & Tinggi \\
$1,8<\mathrm{N} \leq 2,6$ & Sedang \\
$1,0<\mathrm{N} \leq 1,8$ & Rendah \\
$0<\mathrm{N} \leq 1$ & Sangat Rendah \\
\hline
\end{tabular}

Tabel 2 Kriteria Minat Belajar siswa

\begin{tabular}{cc}
\hline Rentang Skor & Kriteria \\
\hline $4,0<\mathrm{N} \leq 5$ & Sangat tinggi \\
$3,6<\mathrm{N} \leq 4$ & Tinggi \\
$3,0<\mathrm{N} \leq 3,6$ & Sedang \\
$2,0<\mathrm{N} \leq 3$ & Rendah \\
$1<\mathrm{N} \leq 2$ & Sangat Rendah \\
\hline
\end{tabular}

HASIL DAN PEMBAHASAN

\begin{abstract}
A. Hasil Penelitian
Pada bagian ini dipaparkan penyajian data analisis hasil penelitian Pada bagian ini hanya akan mencangkup hasil penelitian untuk menjawab rumusan masalah, namun akan dibahas secara umum terlebih dahulu. Untuk mempermudah dan memberikan gambaran yang jelas mengenai kemampuan pemahaman konsep matematis siswa ditinjau dari minat belajar maka akan dijelaskan terlebih dahulu mengenai data hasil tes kemampuan pemahaman konsep matematis siswa dan hasil angket minat belajar siswa secara umum adalah sebagai berikut.
\end{abstract}

1. Analisis data hasil tes kemapuan pemahaman konsep matematis siswa dalam menyelesaikan soal.

Tes kemampuan pemahaman konsep matematis siwa dilakukan peneliti pada hari selasa tanggal 19 November 2019 di kelas VII A SMP Negeri 8 Singkawang yang terdiri dari 30 siswa. Jawaban dari hasil kerja tes siswa selanjutnya akan dikoreksi dan ditabulasi. Dari tabulasi jawaban siswa ditentukan kategori tingkat kemampuan pemahaman konsep matematis siswa, misalnya tergolong rendah, sedang ataupun tinggi.

Setelah dilakukan penganalisis data hasil tes kemampuan pemahaman konsep matematis siswa yang dilihat dari keseluruhan skor total dari keempat indikator pemahaman konsep matematis siswa diperoleh data kemampuan pemahaman konsep matematis siswa tiap kategori disajikan dalam Tabel 3 sebagai berikut.

Tabel 3 kriteria kemampuan pemahaman konsep matematis siswa 


\begin{tabular}{cc} 
Journal of Educational Review and Re \\
Vol. 3 No. 2, December 2020: 86-98 \\
e-ISSN: 2597-9760, p-ISSN: 2597-9752 \\
\hline $2,9<\mathrm{N} \leq 4,0$ & Sangat tinggi \\
$2,5<\mathrm{N} \leq 2,9$ & Tinggi \\
$1,8<\mathrm{N} \leq 2,5$ & Sedang \\
$1,0<\mathrm{N} \leq 1,8$ & Rendah \\
$0<\mathrm{N} \leq 1,0$ & Sangat Rendah \\
\hline
\end{tabular}

Berdasarkan Tabel 3 digambarkan kemampuan pemahaman konsep matematis siswa setiap kategori seperti Tabel 4 sebagai berikut.

Tabel 4 kemampuan pemahaman konsep matematis tiap kategori

\begin{tabular}{ccccc}
\hline Kategori & Banyak Siswa & Jumlah Skor & $\begin{array}{c}\text { Rata-Rata } \\
\text { Skor }\end{array}$ & $\begin{array}{c}\text { Kategori } \\
\text { Rata-Rata }\end{array}$ \\
\hline $\begin{array}{c}\text { Sangat Tinggi } \\
\text { Tinggi }\end{array}$ & 24 & 320 & 13,3 & \\
Sedang & 2 & 22 & 11 & Sangat \\
Total & 4 & 36 & 9 & Tinggi \\
\hline
\end{tabular}

Berdasarkan Tabel 4 digambarkan kemampuan pemahaman konsep matematis siswa setiap kategori seperti gambar Grafik 1 sebagai berikut.

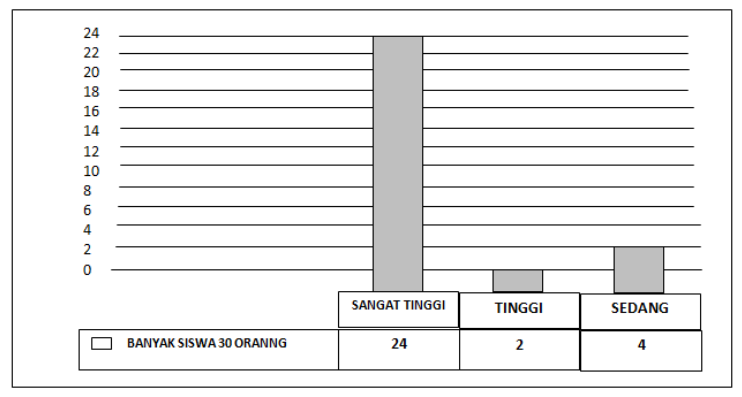

Gambar 1 Grafik kemampuan pemahaman konsep matematis tiap kategori.

Dari Tabel 4 dan Gambar 1 diatas dapat terlihat bahwa kemampuan pemahaman konsep matematis siswa paling banyak berada pada kategori sangat tinggi yaitu 24 siswa ,sedangkan kemampuan pemahaman konsep matematis siswa yang berada pada kategori tinggi yaitu 2 siswa dan kategori sedang yaitu 4 siswa, hal ini berarti bahwa rata-rata kemampuan pemahaman konsep matematis siswa kelas VII SMP Negeri 8 Singkawang berada pada kategori sangat tinggi.

Tabel 5 Kemampuan pemahaman konsep matematis siswa ditinjau dari minat belajar siswa tinggi

\begin{tabular}{|c|c|c|c|c|c|}
\hline \multirow[b]{2}{*}{ No } & \multirow{2}{*}{ Nama Siswa } & \multicolumn{4}{|c|}{ Jumlah Skor } \\
\hline & & Tes & Kategori & Angket & Kategori \\
\hline 1. & S-01 & 3,8 & Sangat Tinggi & 3,8 & Tinggi \\
\hline 2. & S-16 & 3,4 & Sangat Tinggi & 3,9 & Tinggi \\
\hline 3. & $S-21$ & 3,0 & Sangat Tinggi & 3,9 & Tinggi \\
\hline 4. & $S-22$ & 3,0 & Sangat Tinggi & 3,6 & Tinggi \\
\hline & Total & 13,2 & Sangat Tinggi & 15,2 & Tinggi \\
\hline
\end{tabular}


Tabel 6 Kemampuan pemahaman konsep matematis siswa ditinjau dari minat belajar siswa Sedang

\begin{tabular}{|c|c|c|c|c|c|}
\hline \multirow{2}{*}{ No } & \multirow{2}{*}{ Nama Siswa } & \multicolumn{4}{|c|}{ Jumlah Skor } \\
\hline & & Tes & Kategori & Angket & Kategori \\
\hline 1. & S-02 & 3,0 & Sangat Tinggi & 3,2 & Sedang \\
\hline 2. & S-03 & 3,0 & Sangat Tinggi & 3,5 & Sedang \\
\hline 3. & S-04 & 3,8 & Sangat Tinggi & 3,3 & Sedang \\
\hline 4. & S-05 & 3,8 & Sangat Tinggi & 3,3 & Sedang \\
\hline 5. & S-09 & 3,4 & Sangat Tinggi & 3,0 & Sedang \\
\hline 6. & $S-10$ & 3,0 & Sangat Tinggi & 3,0 & Sedang \\
\hline 7. & S-11 & 2,3 & Sedang & 3,1 & Sedang \\
\hline 8. & S-14 & 3,6 & Sangat Tinggi & 3,4 & Sedang \\
\hline 9. & S-17 & 3,8 & Sangat Tinggi & 3,3 & Sedang \\
\hline 10. & S-18 & 3,0 & Sangat Tinggi & 3,0 & Sedang \\
\hline 11. & S-19 & 3,0 & Sangat Tinggi & 3,3 & Sedang \\
\hline 12. & $S-20$ & 2,3 & Sedang & 3,3 & Sedang \\
\hline 13. & S-24 & 3,8 & Sangat Tinggi & 3,2 & Sedang \\
\hline 14. & S-25 & 3,0 & Sangat Tinggi & 3,0 & Sedang \\
\hline 15. & S-27 & 2,3 & Sedang & 3,5 & Sedang \\
\hline 16. & S-28 & 2,8 & Tinggi & 3,4 & Sedang \\
\hline 17. & S-29 & 3,8 & Sangat Tinggi & 3,4 & Sedang \\
\hline 18. & $\mathrm{~S}-30$ & 2,8 & Tinggi & 3,0 & Sedang \\
\hline & Total & $\mathbf{5 6 , 5}$ & Sangat Tinggi & 58,2 & Sedang \\
\hline
\end{tabular}

Tabel 7 Kemampuan pemahaman konsep matematis siswa ditinjau dari minat belajar siswa rendah

\begin{tabular}{cccccc}
\hline \multirow{2}{*}{ No } & Nama Siswa & & \multicolumn{4}{c}{ Jumlah Skor } \\
& & Tes & Kategori & Angket & Kategori \\
\hline $\mathbf{1 .}$ & S-06 & 3,8 & Sangat Tinggi & 2,8 & Rendah \\
$\mathbf{2 .}$ & S-07 & 3,0 & Sangat Tinggi & 2,8 & Rendah \\
$\mathbf{3 .}$ & S-08 & 3,6 & Sangat Tinggi & 2,9 & Rendah \\
$\mathbf{4 .}$ & S-12 & 3,0 & Sangat Tinggi & 2,9 & Rendah \\
$\mathbf{5 .}$ & S-13 & 3,6 & Sangat Tinggi & 2,8 & Rendah \\
$\mathbf{6 .}$ & S-15 & 3,0 & Sangat Tinggi & 2,7 & Rendah \\
$\mathbf{7 .}$ & S-23 & 3,8 & Sangat Tinggi & 2,6 & Rendah \\
$\mathbf{8 .}$ & S-26 & 2,3 & Sedang & 2,9 & Rendah \\
& Total & $\mathbf{2 6 , 1}$ & Sangat Tinggi & $\mathbf{2 2 , 4}$ & Rendah \\
\hline
\end{tabular}

\section{Analisis data hasil angket minat belajar siswa}

Penyebaran angket minat belajar siswa juga dilakukan peneliti pada hari selasa 19 November 2019 di kelas VII A SMP Negeri 8 Singkawang yang terdiri dari 30 siswa. Penganalisisan hasil angket minat belajar siswa dilihat dari keseluruhan skor dari keempat indikator minat belajar siswa. Minat belajar siswa pada Kriteria disajikan dalam bentuk Tabel 8 sebagai berikut.

\section{Tabel 8 Kriteria Minat Belajar Siswa}

\begin{tabular}{ccc}
\hline Rentang Skor & Kriteria & Banyak Siswa \\
\hline Sangat Tinggi & $4,0<\mathrm{N} \leq 5,0$ & 0 \\
Tinggi & $3,5<\mathrm{N} \leq 4,0$ & 4 \\
Sedang & $2,9<\mathrm{N} \leq 3,5$ & 18 \\
Rendah & $2,0<\mathrm{N} \leq 2,9$ & 8 \\
Sangat Rendah & $1<\mathrm{N} \leq 2,0$ & 0 \\
\hline
\end{tabular}


Berdasarkan kriteria minat belajar pada tabel 8 diatas dapat disajikan dalam tabel minat belajar dalam kategori Tabel 9, sebagai berikut.

Tabel 9 minat belajar siswa tiap kategori

\begin{tabular}{ccccc}
\hline Kategori & Banyak Siswa & $\begin{array}{c}\text { Jumlah Skor } \\
\text { Angket }\end{array}$ & $\begin{array}{c}\text { Rata-Rata Skor } \\
\text { Angket }\end{array}$ & $\begin{array}{c}\text { Kategori Rata- } \\
\text { Rata Angket }\end{array}$ \\
\hline Tinggi & 4 & 369 & 92,25 & \\
Sedang & 18 & 1407 & 78,16 & \\
Rendah & 8 & 545 & 68,12 & Sedang \\
Total & 30 & 2321 & 77,36 & \\
& & & & \\
\hline
\end{tabular}

Berdasarkan Tabel 9 digambarkan grafik minat belajar siswa kelas VII SMP Negeri 8 Singkawang pada tiap kategori seperti pada Gambar 2 Grafik sebagai berikut.

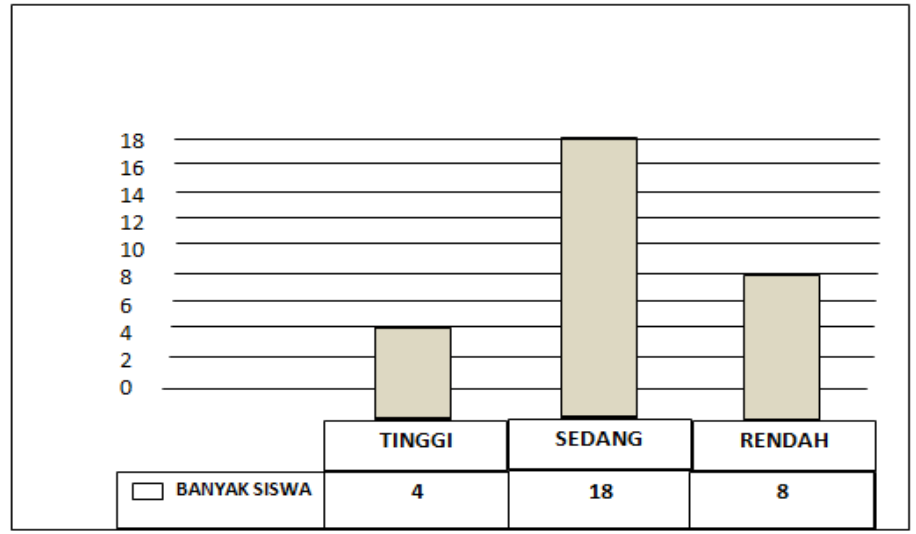

\section{Gambar 2 Grafik Minat belajar tiap kategori}

Dari Tabel 9 dan Gambar 2 grafik diatas terlihat bahwa minat belajar siswa paling banyak berada pada kategori sedang dan paling sedikit berada pada kategori tinggi. Hal ini berarti bahwa rata-rata minat belajar siswa kelas VII SMP Negeri 8 Singkawang berada pada kategori sedang.

\section{B. Pembahasan}

Hasil analisis data berdasarkan tes kemampuan pemahaman konsep matematis siswa dan angket pada materi himpunan, diperoleh data rentang persentase masing-masing indikator pemahaman konsep matematis siswa pada pada materi himpunan ditinjau dari minat belajar, berikut pembahasan kemampuan pemahaman konsep matematis siswa secara perindikator pada tiap kategori, sebagai berikut :

\section{Kemampuan pemahaman konsep matematis siswa pada materi himpunan.}

Untuk mengukur kemampuan pemahaman konsep matematis siswa kelas VII SMP Negeri 8 Singkawang digunakan instrumen berupa soal tes uraian mencangkup beberapa indikator dalam pemahaman konsep matematis siswa, indikator tersebut adalah kemampuan menyatakan ulang sebuah konsep, kemampuan mengklasifiasi objek menurut sifat-sifat sesuai dengan konsepnya, kemampuan menyajikan konsep kedalam macam bentuk representasi matematis dan kemampuan menggunakan , memanfaatkan dan memilih prosedur tertentu.

Tes kemampuan pemahaman konsep matematis dilaksanakan peneliti pada hari selasa tanggal 19 November 2019 di kelas VII A SMP Negeri 8 Singkawang yang terdiri dari 30 siswa, Setelah melakukan tes tertulis selesai dilakukan, selanjutnya pekerjaan siswa diperiksa dan dilanjutkan dengan penskoran, kemudian langkah selanjutnya yang dilakukan adalah menganalisisi hasil yang diperoleh, yaitu dengan menghitung jumlah persentase jawabana yang benar, yaitu sebagai berikut :

a. Indikator 1 menyatakan ulang sebuah konsep

Dari hasil tes kemampuan pemahaman konsep matematis siswa pada materi himpunan, diperoleh rata- 
rata persentase pencapaian pada indikator 1 yaitu menyatakan ulang sebuah konsep pada soal no 3 yaitu contoh soal berbunyi : Tuliskan apa yang kalian ketahui dari gambar dibawah dengan cara mendaftar anggota himpunannya. Apakah himpunan B merupakan himpunan semesta dari himpunan A ?

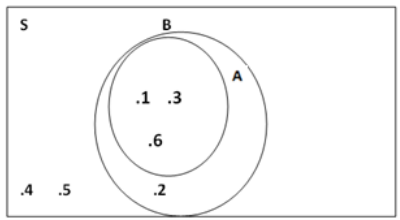

Gambar 3 Diagram Venn

Dari soal no 3 terdapat 30\% siswa yang bisa menjawab dengan benar pertanyaan soal no 3 dan $70 \%$ nya lagi siswa belum memahami pertanyaan dari soal no 3 dikarenakan siswa masih belum memahami pertanyaan soal yang diberikan. Basuki (2012), dalam penelitiannya menyatakan kesulian siswa dalam menyelesaikan soal disebabkan oleh belum memahami apaditanyakan pada soal.

Cuplikan jawaban siswa terdapat 30\% siswa dapat menjawab pada soal no 3.

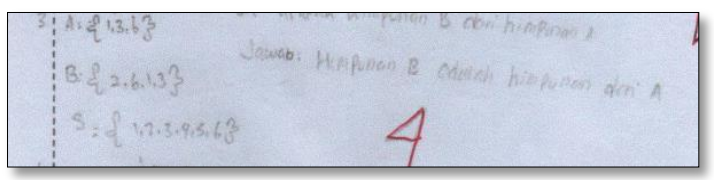

Gambar 4 Hasil jawaban siswa

Cuplikan jawaban siswa terdapat 70\% siswa dapat menjawab pada soal no 3.

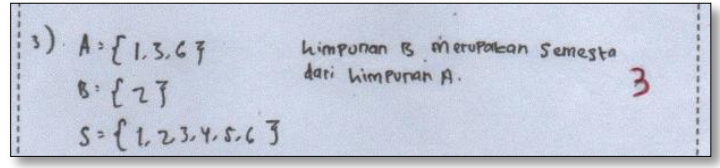

Gambar 5 Hasil jawaban siswa

a. Indikator 2 mengklasifiasi objek menurut sifat-sifat sesuai dengan konsepnya.

Dari hasil tes kemampuan pemahaman konsep matematis siswa pada materi himpunan, diperoleh ratarata persentase pencapaian pada indikator 2 yaitu mengklasifiasi objek menurut sifat-sifat sesuai dengan konsepnya. Yaitu pada soal no 4 yaitu contoh soal berbunyi : Diketahui himpunan semesta sebagai berikut $S=\{0,1,2,3,4,5,6,7,8,9\}$ himpunan $A=\{2,4,6,8\}$ dan himpunan $B=\{3,6,9\}$, Gambarkan lah diagram vennya dan jelaskan menurut kalian gambar yang kalian buat ?

Dari soal no 4 terdapat $40 \%$ siswa yang bisa menjawab dengan benar pertanyaan soal no 4 dikarenakan sebagian siswa sudah memahami bentuk pertanyaan dan menggambarkan diagram venn dengan tepat dari soal yang diberikan dan $60 \%$ siswa masih belum memahami pertanyaan dari soal no 4 dikarenakan siswa masih belum memahami bentuk soal sehingga siswa masih belum tepat dalam menggambarkan diagram venn pada soal no 4.Menurut Muncarno (2008) kesulitan dalam mengerjakan soal disebabkan karena siswa kurang cermat dalam membaca dan memahamikalimat.

Cuplikan jawaban siswa benar pada soal no 4 persentase $40 \%$

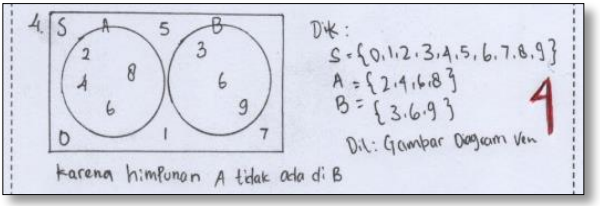

Gambar 6 Hasil jawaban siswa 
Cuplikan jawaban siswa salah no 4 persentase $60 \%$

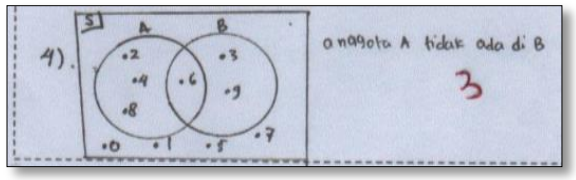

Gambar 7 Hasil jawaban siswa

b. Indikator 3 menyajikan konsep kedalam macam bentuk representasi matematis.

Dari hasil tes kemampuan pemahaman konsep matematis siswa pada materi himpunan, diperoleh ratarata persentase pencapaian pada indikator 3 yaitu menyajikan konsep kedalam macam bentuk representasi matematis. Yaitu pada soal no 1 , yaitu contoh soal berbunyi : soal no 1. Yogi diberi tugas oleh guru untuk mendata dua buah himpunan yaitu himpunan P dan R. P Diketahui himpunan bilangan asli yang kurang dari 10 dan $\mathrm{R}$ adalah himpunan bilangan genap yang tidak lebih dari 20 . Ditanya nyatakan himpunan tersebut dengan mendaftar anggotanya ?

Dari soal no 1 terdapat $80 \%$ siswa yang bisa menjawab dengan benar pertanyaan soal no 1 dikarenakan siswa sudah memahami bentuk pertanyaan dari soal yang diberikan dan $20 \%$ nya lagi siswa masih belum lengkap dalam menuliskan secara lengkap karena tidak dituliskan dalam lembar jawaban diketahui dan ditanyakan, sehingga siswa cenderung menuliskan jawaban secara langsung tanpa menuliskan tahap-tahap penyelesaian.

Cuplikan jawaban siswa benar pada soal no 1 persentase $80 \%$

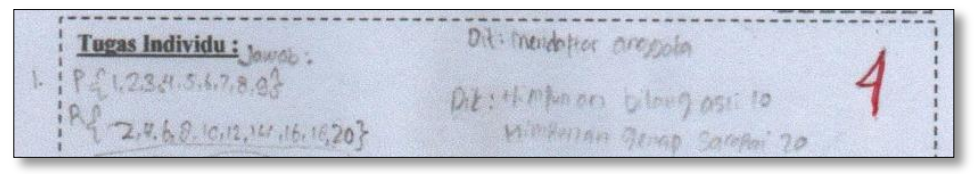

Cuplikan jawaban siswa salah pada soal no 1 persetase $20 \%$

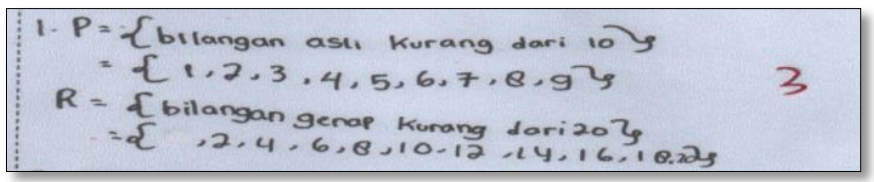

Gambar 9 Hasil jawaban siswa

c. Indikator 4 kemampuan menggunakan, memanfaatkan dan memilih prosedur tertentu.

Dari hasil tes kemampuan pemahaman konsep matematis siswa pada materi himpunan, diperoleh ratarata persentase pencapaian pada indikator 4 yaitu kemampuan menggunakan , memanfaatkan dan memilih prosedur tertentu. Yaitu pada soal no 2a, 2b , yaitu contoh soal no 2 berbunyi : Siswa kelas VII A sejumlah 36 siswa. Setelah di data ternyata 17 anak menyukai olahraga voli, 14 anak menyukai olahraga basket, dan 4 anak menyukai keduanya.

Ditanya :

a.) Gambarkan diagram venn nya!

b.)Berapa anak yang tidak menyukai olahraga voli dan basket?

Dari soal no $2 \mathrm{a}, 2 \mathrm{~b}$, terdapat $40 \%$ siswa yang bisa menjawab dengan benar pertanyaan soal no 2a, dikarenakan siswa sudah bisa menggambarkan kedalam bentuk diagram venn dan $60 \%$ siswa belum memahami pertanyaan dari bentuk soal no $2 \mathrm{~b}$, dalam menyelesaikan perhitungan pada soal no 2b.Menurut Paridjo (2008: 7) Kesulitan siswa dalam menyelesaikan soal cerita adalah kesulitan siswa memahami cerita dari soal tersebut. 


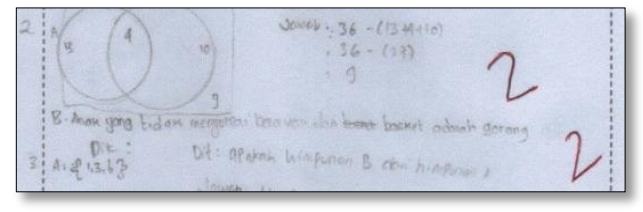

Gambar 10 Hasil jawaban siswa

Cuplikan jawaban siswa salah pada soal no.2a dan 2b. persentase $60 \%$

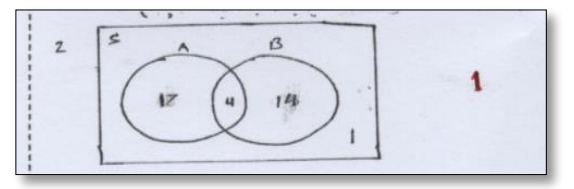

Gambar 11 Hasil jawaban siswa

\section{Minat belajar siswa}

Untuk mengukur minat belajar siswa pada kemampuan pemahaman konsep matematis siswa ditinjau dari minat belajar siswa kelas VII SMP Negeri 8 Singkawang digunakan instrumen angket minat belajar siswa mencangkup beberapa indikator dalam minat belajar siswa, indikator tersebut adalah perasaan senang, keterlibatan siswa, ketertarikan siswa dan perhatian siswa. Peneliti membagikan lembar angket siswa pada hari selasa tanggal 19 November 2019 di kelas VII A SMP Negeri 8 Singkawang yang terdiri dari 30 siswa. Adapun penyajian dari indikator minat belajar siswa sebagai berikut :

a. Perasaan senang

Apabila seorang siswa memiliki perasaan senang terhadap pelajaran tertentu maka tidak akan ada rasa terpaksa untuk belajar. Contohnya: yaitu senang mengikuti pelajaran, tidak ada perasaan bosan, dan hadir saat pelajaran.

b. Keterlibatan Siswa

Ketertarikan seseorang akan obyek yang mengakibatkan orang tersebut senang dan tertarik untuk melakukan atau mengerjakan kegiatan dari obyek tersebut. Contohnya: aktif dalam diskusi, aktif bertanya, dan aktif menjawab pertanyaan dari guru.

c. Ketertarikan Siswa

Berhubungan dengan daya dorong siswa terhadap ketertarikan pada sesuatu benda, orang, kegiatan atau bias berupa pengalaman afektif yang dirangsang oleh kegiatan itu sendiri. Contohnya: antusias dalam mengikuti pelajaran, tidak menunda tugas dari guru.

d. Perhatian Siswa

Merupakan hal yang dianggap sama dalam penggunaan sehari-hari, perhatian siswa merupakan konsentrasi siswa terhadap pengamatan dan pengertian, dengan mengesampingkan yang lain. Siswa memiliki minat pada obyek tertentu maka dengan sendirinya akan memperhatikan obyek tersebut.Contohnya: mendengarkan penjelasan guru dan mencatat materi.

\section{Faktor-Faktor yang mempengaruhi Kemampuan Pemahaman Konsep Matematis Siswa dan Minat Belajar Siswa.}

Dari hasil wawancara terdapat 3 tingkat kemampuan siswa dalam belajar dan masuk dalam kategori tinggi,sedang dan rendah, dalam penelitian, menurut Syah (2003: 132), yaitu: Faktor internal (dalam diri siswa) dan Faktor eksternal (lingkungan dan sekitar).saat peneli melakukan tes wawancara pada salah satu siswa terdapat hal yang sama yang dirasakan oleh siswa sehingga terdapat salah satu fator yang mempengaruhi siswa dalam proses belajar dalam menyelesaikan suatu masalah.

Dari hasil wawancara dengan siswa kemampuan pemahaman konsep dalam kategori tinggi, sedang dan rendah serta minat belajar tinggi, sedang dan rendah didapat dari sebagian besar siswa dalam kemampuan pemahaman konsep ditinjau dari minat belajar siswa sebagai berikut :

a. 1.) kemampuan pemahaman konsep sangat tinggi dan minat belajar tinggi disebabkan oleh faktor internal yaitu, semangat belajar dan minat siswa sangat tinggi.

2.) Kemampuan Pemahaman Konsep Tinggi, Minat Belajar Tinggi, disebabkan oleh faktor 
internal, yaitu motivasi belajar siswa sangat tinggi.

3.) Kemampuan Pemahaman Konsep Tinggi, Minat Belajar Sedang, disebabkan oleh faktor internal yaitu kondisi jasmani siswa sangat baik.

4.) Kemampuan Pemahaman Konsep Tinggi, Minat Belajar Rendah, disebabkan oleh faktor eksternal, yaitu faktor materi pembelajaran.

b. 1.) Kemampuan Pemahaman Konsep Sedang, Minat Belajar Tinggi, disebabkan oleh faktor internal, yaitu minat siswa kuat ingin mengatahui lebih jauh materi.

2.) Kemampuan Pemahaman Konsep Sedang, Minat Belajar Sedang, disebabkan oleh faktor internal, yaitu kondisi jasmani siswa dalam keadaan baik.

3.) Kemampuan Pemahaman Konsep Sedang, Minat Belajar Rendah, disebabkan oleh faktor eksternal, yaitu minat belajar siswa rendah.

\section{KESIMPULAN DAN SARAN}

Berdasarkan hasil penelitian dan pembahasan pada bab sebelumnya, penelitian yang dilakukan peneliti di SMP Negeri 8 Singkawang dapat disimpulkan sebagai berikut :

Kemampuan pemahaman Konsep perindikator ditinjau dari minat belajar :Indikator 1 menyatakan ulang sebuah konsep, Dari hasil tes kemampuan pemahaman konsep matematis siswa pada materi himpunan, diperoleh siswa masih belum memahami pertanyaan soal yang diberikan. Indikator 2 mengklasifiasi objek menurut sifat-sifat sesuai dengan konsepnya, Dari hasil tes kemampuan pemahaman konsep matematis siswa masih belum tepat dalam menggambarkan kemampuan pemahan konsep dengan baik. Indikator 3 menyajikan konsep kedalam macam bentuk representasi matematis. Dari hasil tes kemampuan pemahaman konsep matematis siswa cenderung menuliskan jawaban secara langsung tanpa menuliskan tahap-tahap penyelesaian. Indikator 4 kemampuan menggunakan, memanfaatkan dan memilih prosedur tertentu. Dari hasil tes kemampuan pemahaman konsep matematis siswa belum memahami pertanyaan dari bentuk soal serta menyelesaikan perhitungan dengan baik.

Faktor-faktor yang mempengaruhi pemahaman konsep dan minat belajar siswa dari materi himpunan yaitu : Faktor internal (dalam diri siswa) dan Faktor eksternal (lingkungan dan sekitar). Dengan persentase kemampuan pemahaman konsep faktor internal $10 \%$ kondisi jasmani mental pada siswa dan kesehatan tubuh siswa dan eksternal 90\% factor lingkungan yang mempengaruhi siswa yaitu seperti pergaulan bebas dampak yang kurang baik bagi siswa, kemudian persentase minat belajar siswa pada faktor internal $20 \%$ mempengaruhi semagangat belajar siswa faktor eksternal $80 \%$.dari lingkungan luar, masyarakat yang kurang mendukungnya kerjasama didalam lingkungan keluarga. 
Ahmadi. (1990). Pendekatan Saintifik dan Kontekstual dalam Pembelajaran. Jakarta: Ghalia Indonesia. Arikunto. (2015). Metode Penelitian Kualitatif Teori dan Praktik. Jakarta: Bumi Aksara.

Arikunto. (2015). Penelitian Tindakan Kelas. Jakarta: PT Bumi Aksara

Basuki. (2015). Faktor-Faktor Penyebab Kesepian Terhadap Tingkat Depresi Pada Lansia. Jurnal Psikologi. 4(1), 713-718.

Dahar. (2014), Kemampuan Pemahaman Konsep Matematis ,universitas IKIP PGRI Pontianak,3(1), 8081

Daryanto. (2014). Pendekatan Pembelajaran Saintifik Kurikulum 2013. Yogyakarta: Gava Media.

Depdiknas.(2013). Kurikulum 2013: Standar Isi Mata Pelajaran Matematika Untuk SMP/MTs.

Fahmy. (2018), pemahaman konsep dan minat belajar, jurnal manajemen bisnis, 5(1), 50-53.

Fahinu. (2013).Menigkatkan kemampuan Motivasi dalam mendorong minat belajar siswa, Jakarta :Kencana

Jihad, A., \& Abdul Haris. (2012). Evaluasi Pembelajaran. Yogyakarta: Multi Pressindo.

Kaniawaty, R. (2016). Mengembangkan Kemampuan Berpikir Kritis dan Kreatif Matematik Serta Motivasi Siswa SMP di Kabupaten Bandung Melalui Metode Tutor Sebaya. Tesis Pada Pasca prasarjana STKIP SILIWANGI Bandung: tidak dipublikasikan.

Lestari, K. E. (2014). Implementasi Brain-Based Learning untuk meningkatkan kemampuan koneksi dan kemampuan berpikir kritis serta motivasi belajar siswa SMP. JUDIKA (JURNAL PENDIDIKAN UNSIKA). 2(1), 85-88.

Lestari, K. E., \& Mokhammad Ridwan Yudhanegara. (2017). Penelitian Pendidikan Matematika. Jakarta: Refika Aditama.

Lisnawaty.(1993). Psikologi Pembelajaran terhadap prestasi siswa. Bandung: Wancana Prisma.

M. Hosnan. (2014). Pendekatan Saintifik dan Kontekstual dalam Pembelajaran Abad 21. Bogor: Ghalia Indonesia.

Martinus, Yamin. (2008), Minat Belajar Siswa Dalam Pendekatan Kualitatif, Yogyakarta:Gava Media.

Majid, A. (2014). Strategi Pembelajaran. Bandung: PT. Remaja Rosdakarya.

Muncarno.(2008). Prosedur Penelitian Suatu Pendekatan Praktek. Jakarta: Rineka Cipta.

NCTM. (2000). Principles and Standart For School Mathematics. Reston : NCTM. Inc

Novtiar, C., \& Aripin, U. (2017). Meningkatkan kemampuan pemahaman konsep matematis dan kepercayaan diri siswa SMP melalui pendekatan open ended. Prisma, 6(2), 34-37.

Nur, I. R. D. (2016). Meningkatkan Kemampuan pemahaman konsep Dan Kemandirian Belajar Siswa Dengan Menggunakan Model Pembelajaran Brain Based Learning. JUDIKA (Jurnal Pendidikan Unsika), 4(1), 57-60.

Nuryanti, L., Zubaidah, S., \& Diantoro, M. (2018). Analisis Kemampuan pemahaman konsep matematis Siswa SMP. Jurnal Pendidikan: Teori, Penelitian, vol 1, no 2 ,24-27.

Permendikbud No.24 Tahun 2016 tentang kompetensi inti dan kompetensi dasar pembelajaran pada kurikulum 2013 pada pendidikan SD,SMP, SMA dan SMK. Jakarta: Kementerian Pendidikan dan Kebudayaan RI.

Paridjo. (2008). Belajar dan Faktor-Faktor yang mempengaruhinya. Jakarta: Rineka Cipta.

Prasetyo, B., \& Jannah, L. M. (2014). Metode Penelitian Kualitatif Teori dan Aplikasi, Pangkal Pinang : Gramedia.

Prayogi, A., \& Widodo, A. T. (2017). Kemampuan Berpikir Kritis Ditinjau dari Karakter Tanggung Jawab pada Model Brain Based Learning. Unnes Journal of Mathematics Education Research, vol 1, no 2, h 89-95.

Rusman. (2017). Belajar \& Pembelajaran Berorientasi Standar Proses Pendidikan. Jakarta: Kencana.

Satori \& Komariah.(2015). Metodologi penelitian Kualitatif, Bandung: Alfabeta.

Sanjaya, W. (2015). Perecanaan dan desain sistem perencanaan. Jakarta: Kencana.

Siregar, S. (2015). Statistika Deskriptif Untuk Penelitian Dilengkapi Perhitungan Manual dan Aplikatif. Jakarta: Rajawali Press.

Slamet. (2003). Meningkatkan kemampuan pemahaman konsep matematis siswa SMP melalui pendekatan kualitatif. Prisma, 2(2), 57-58.

Sugiyono. (2015). Metode Penelitian Pendidikan. Bandung: Alfabeta.

Sugiyono. (2017). Metode Penelitian Kualitatif (Deskriptif), Bandung. 
Sukasono. (2006). Evaluasi Pembelajaran Matematika. Lubuk Linggau: STKIP-PGRI Lubuk Linggau. Syarifah. (2014), Minat Belajar Siswa Sistematis, Jakarta: PT. Rineka Cipta.

Syah. (2003). Minat Belajar. Yogyakarta: Pustaka Belajar.

Tirtaharjo, U. \& Sulo, L.(2005). Mengembangkan kemampuan pemahaman konsep matematis siswa, Yogyakarta:Multi pesindo.

Uno, H. B. (2014). Teori Motivasi \& Pengukurannya. Jakarta: Pt. Bumi Aksara.

Usman.(1993). Prosedur Penelitian Suatu Pendekatan prakti. Yogyakarta : Rineka Cipta.

Wirayat, Agung. (2015), Evaluasi Pembelajaran Terhadap Minat Belajar Siswa, Jakarta : Erlangga. Yamin, Martinus.(2008), minat belajar siswa dalam pendekatan kualitatif, Yogyakarta:Gava Media. 